\title{
SWAMEDIKASI PEMBERIAN ANTISEPTIK DAN PENYULUHAN PENCEGAHAN PENYAKIT RABIES DENGAN MEDIA BOOKLET
}

\author{
Wahyuni Aziza'), Frenky Aipassa1), Ramdhani M Natsir ${ }^{1}{ }^{1}$ \\ 1)Program Studi Teknologi Laboratorium Medis, Poltekkes Kemenkes Maluku, Ambon, Indonesia \\ Corresponding author : Ramdhani M Natsir \\ E-mail : Ramdhani_apt@yahoo.com
}

Diterima 21 Oktober 2020, Disetujui 29 Oktober 2020

\begin{abstract}
ABSTRAK
Rabies (penyakit anjing gila) merupakan penyakit yang disebabkan oleh virus, bersifat akut dan menyerang susunan saraf pusat. Bentuk pencegahan penyakit rabies adalah melakukan swamedikasi pemberian antiseptik sebagai penanganan awal jika digigit hewan penular rabies. Swamedikasi atau pengobatan mandiri adalah kegiatan atau tindakan mengobati diri sendiri dengan obat seperti antiseptik atau tanpa resep secara tepat dan bertanggung jawab (rasional). Tujuan kegiatan ini adalah meningkatkan pemahaman tentang bahaya rabies dan cara penularannya serta meningkatkan pengetahuan dalam melakukan penanganan awal luka gigitan hewan penular rabies melalui swamedikasi pemberian antieptik. Kegiatan ini dilaksanakan dalam bentuk penyuluhan melalui media booklet. Pada kegiatan ini dilakukan tahapan pre dan post test sebelum dan setelah dilakukan penyuluhan. Secara statistik hasil dari pelaksanaan pre test dan post test diuji analisis dengan menggunakan analisis paired sample $t$-test dengan hasil perolehan adalah $p=0.006(r=0,589)$. Hal ini menunjukkan bahwa terdapat hubungan pengetahuan antara sebelum dan sesudah dilakukan kegiatan penyuluhan. Hal ini mengindikasikan bahwa pemberian swamedikasi pemberian antiseptik dan penyuluhan pencegahan penyakit rabiet sangat mempengaruhi tingkat pengetahuan masyarakat.
\end{abstract}

Kata kunci: swamedikasi; antiseptik; rabies.

\begin{abstract}
Rabies (mad dog disease) is a disease caused by a virus, is acute and attacks the central nervous system. The form of prevention of rabies is to self-medicate the administration of antiseptics as an initial treatment if bitten by an animal that transmits rabies. Self-medication or self-medication is the activity or act of treating yourself with drugs such as antiseptics or without a prescription appropriately and responsibly (rationally). The purpose of this activity is to increase understanding of the dangers of rabies and how it is transmitted and to increase knowledge in early handling of bite wounds of rabies-infected animals through self-medicated administration of antieptics. This activity is carried out in the form of counseling through booklet media. In this activity, the pre and post test stages were carried out before and after counseling. Statistically, the results of the pre-test and post-test implementation were analyzed using paired sample t-test analysis with the results of $p=0.006(r=0.589)$. This shows that there is a knowledge relationship between before and after extension activities are carried out. This indicates that the provision of self-medicated giving of antiseptics and counseling on the prevention of rabbits greatly affects the level of public knowledge.
\end{abstract}

Keywords: self-medication; antiseptic; rabies.

\section{PENDAHULUAN}

Rabies (penyakit anjing gila) merupakan penyakit yang disebabkan oleh virus, bersifat akut dan menyerang susunan saraf pusat (Kementerian Kesehatan RI, 2019) Penyakit ini menular dari hewan ke manusia dan menyebabkan kematian sebanyak 100\% kasus. Virus rabies dikeluarkan bersama air liur hewan pengidap rabies dan disebarkan melalui luka gigitan atau luka terbuka yang terkena air liur hewan pengidap rabies. Virus rabies tidak bisa masuk melalui kulit yang utuh. Setelah virus rabies masuk melalui luka gigitan, maka selama 2 minggu virus tetap tinggal pada tempat masuk dan daerah sekitarnya. Virus ini kemudian bergerak menuju ujung-ujung saraf hingga sampai ke otak. (Neurologi, 2016)

Gejala rabies yang ditemukan pada manusia pun tidak jauh berbeda. Awalnya pasien akan tampak gelisah, demam dan lemas. Pasien juga mengeluhkan sakit kepala, rasa seperti terbakar, kedinginan dan nyeri tenggorokan selama beberapa hari. Gejala ini kemudian diikuti rasa nyeri, panas disertai 
kesemutan pada tempat bekas luka. Pasien juga tampak cemas dan bereaksi berlabihan terhadap rangsang sentuhan. Selanjutnya, pasien mulai tampak ketakutan berlebihan, merasa haus, takut melihat cahaya, tiupan angin atau suara keras. Pasien akan tampak bingung, gelisah, dan semakin lama berkembang menjadi agresif, mulai berhalusinasi, tubuh gemetaran, kaku atau kejang. Akhirnya pasien akan tampak lemas, semakin berat hingga akhirnya meninggal (Neurologi, 2016)

Swamedikasi atau pengobatan mandiri adalah kegiatan atau tindakan mengobati diri sendiri dengan obat atau tanpa resep secara tepat dan bertanggung jawab (rasional). Makna swamedikasi adalah bahwa penderita sendiri yang memilih obat tanpa resep untuk mengatasi penyakit yang dideritanya. (Yusrizal, 2015) Dalam kehidupan sehari-hari, banyak penyakit dan gangguan kesehatan dapat dikenali dan diobati secara mandiri (swamedikasi) baik oleh penderita maupun oleh orang di sekitarnya. Di Indonesia obat yang dapat digunakan secara swamedikasi adalah obat dari golongan bebas, obat bebas terbatas dan obat keras. Keuntungan swamedikasi menggunakan obat bebas dan obat bebas terbatas antara lain aman bila digunakan sesuai dengan aturan, efektif untuk menghilangkan keluhan (karena $80 \%$ keluhan sakit bersifat self-limiting), efisiensi biaya, waktu, lebih mudah karena pengobatan dilakukan sendiri menggunakan obat yang mudah diperoleh, aman karena obat yang dipakai adalah obat yang telah melewati serangkaian pengujian dan tertera aturan (dosis) pemakaian obat, dan meringankan beban pemerintah dalam keterbatasan jumlah tenaga dan sarana kesehatan di masyarakat. (Kristina et al., 2007)

Salah satu bentuk penanganan awal jika digigit hewan penular rabies. adalah pemberian antiseptik. Melakukan swamedikasi (pengobatan mandiri) pemberian antiseptik dengan indikasi obat yang benar, mencegah penggunaan antiseptik yang salah dan memberikan pengetahuan serta pemahaman dalam penggunaan obat akan berdampak pada kepatuhan pengobatan dan keberhasilan dalam proses penyembuhan. Adanya kegiatan penyuluhan penyakit rabies juga akan memberikan edukasi kepada masyarakat mengenai pencegahan dan bahaya rabies.

Dari hasil pengambilan data di kantor desa terdapat sekitar 200 keluarga yang memiliki hewan penular rabies yaitu anjing. Penularan rabies di umumnya berawal dari suatu kondisi anjing yang tidak dipelihara atau tanpa pemilik (rural rabies) yang berkembang hingga mencapai populasi yang sulit dikendalikan. Keadaan inilah yang menyebabkan daerah di Indonesia menjadi endemis terhadap rabies terutama di dusun amaori desa passo. (Kastania, 2013) Dari hasil pengambilan data di kantor desa terdapat sekitar 200 keluarga yang memiliki hewan penular rabies yaitu anjing. Data di puskesmas passo pada tahun 2017 didapatkan 47 kasus rabies, adanya peningkatan di tahun 2018 didapatkan 52 kasus rabies dan di tahun 2019 dari bulan januari sampai oktober didapatkan 16 kasus. Beberapa kendala yang menjadi faktor penghambat lambatnya penanganan awal rabies ini adalah kurangnya sosialisasi sebagai upaya dalam mencegah bertambahnya jumlah gigitan hewan penular rabies serta kurangnya informasi tentang bahaya rabies.

Berdasarkan kendala tersebut di atas, maka pengabdi berinisiatif untuk melakukan kegiatan swamedikasi pemberian antiseptik dan penyuluhan pencegahan penyakit rabies melalui media booklet di dusun amaori desa passo dengan tujuan umum untuk meningkatkan pemahaman tentang penyakit rabies kepada masyarakat. Adapun tujuan khusus kegiatan ini adalah:

a. Meningkatkan pengetahuan dalam melakukan penanganan awal luka gigitan hewan penular rabies melalui swamedikasi pemberian antieptik dalam bentuk booklet

b. Meningkatkan pemahaman tentang bahaya rabies dan cara penularannya.

\section{METODE}

Metode yang digunakan pada pengabdian kepada masyarakat ini adalah penyuluhan swamedikasi pemberian antiseptik dan pencegahan penyakit rabies melalui media booklet. Kegiatan swamedikasi pemberian antiseptik dan penyuluhan pencegahan penyakit rabies di dusun amaori desa passo dilaksanakan untuk meningkatkan pemahaman tentang penyakit rabies kepada masyarakat. Kegiatan ini dibagi menjadi tiga tahap yaitu pre test sebelum dilakukan penyuluhan, penyuluhan dan post test setelah dilakukan penyuluhan sebagai evaluasi

\section{HASIL DAN PEMBAHASAN}

Peserta yang mengikuti kegiatan pengabdian kepada masyarakat adalah masyarakat yang memiliki hewan peliharaan berjumlah 20 orang yang tinggal didusun amaori passo seperti yang terlihat pada Gambar 1. 


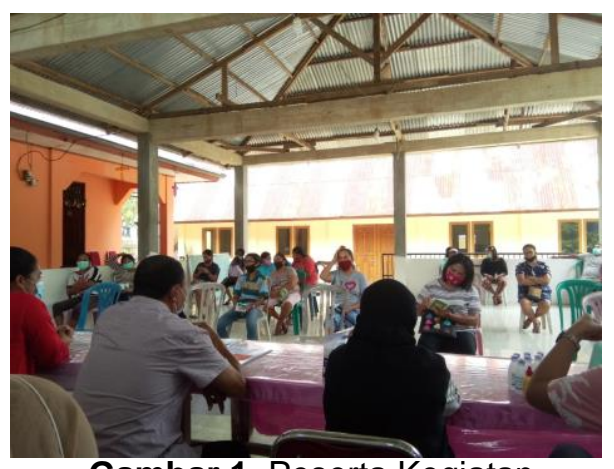

Gambar 1. Peserta Kegiatan

Pelaksanaan kegiatan diawali registrasi masyarakat kegiatan pengabdian kepada masyarakat di Dusun Amaori Passo dilanjutkan dengan pembukaan kegiatan oleh kepala dusun amaori passo. Sebelum dilakukan penyuluhan, peserta diberikan kuisioner pre test untuk menilai kemampuan sebelum kegiatan penyuluhan. Kegiatan pre test dilaksanakan pada hari jumat, 25 september 2020 pukul 10.00 WIT bertempat di dusun amaori passo terlihat pada gambar 2. Selama kegiatan berlangsung peserta yang hadir pada pengisian pre test, hadir juga pada post test (absen terlampir. Soal pre test disesuaikan dengan bahasa masyarakat awam yang terdiri dari 20 soal dengan pilihan jawaban menggunakan skala guttman. Hasil dari pre test ini bermanfaat untuk mengetahui sejauhmana pemahaman masyarakat sebelum diberikan penyuluhan.

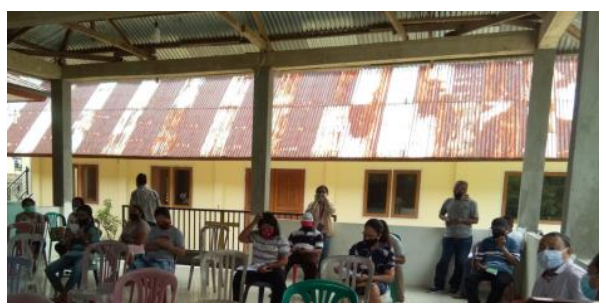

Gambar 2. Peserta Mengisi Kuesioner Pre dan Post Test

Setelah dilakukan pengisian kuesioner pre test, tim pengabdi melakukan penyuluhan. Metode yang digunakan adalah ceramah dan Tanya jawab terlihat pada gambar 3. Materi pada penyuluhan adalah pengertian swamedikasi pemberian antiseptik, jenis antiseptik, pengertian rabies, jenis penyakit rabies, gejala dan tanda rabies, pertolongan pertama jika terkena gigitan dan pencegahan penyakit rabies

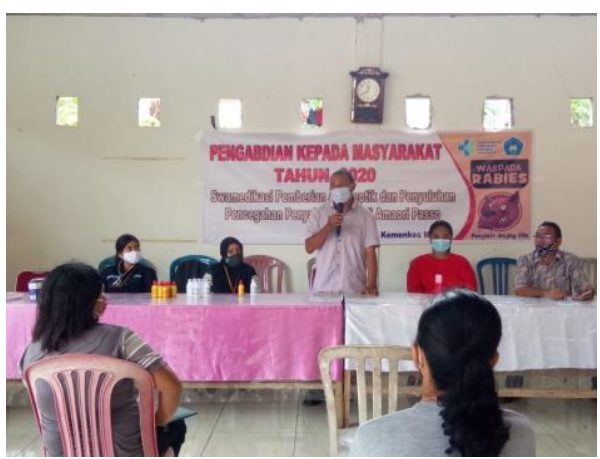

Gambar 3. Penyuluhan

Media booklet yang menarik sebagai media untuk meningkatkan pengetahuan dan sikap masyarakat. Desain booklet dibuat semenarik mungkin dan memilih kalimat yang mudah dipahami oleh masyarakat agar masyarakat mampu menyerap ilmu yang ada dalam booklet tersebut. Materi booklet menampilkan jenis-jenis antiseptik disertai dengan cara penggunaannya dalam pencegahan penyakit rabies terlihat pada gambar 4.

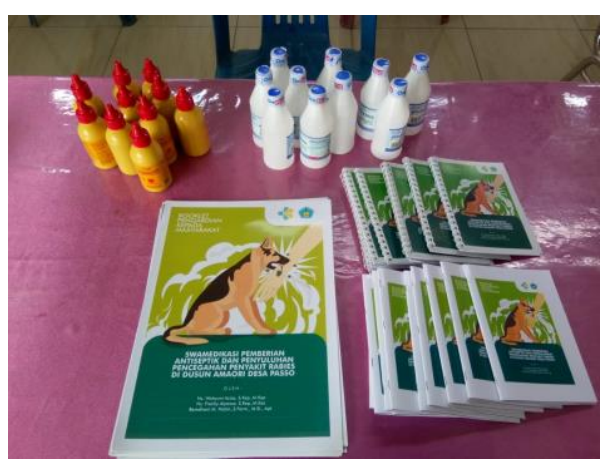

Gambar 4. Antiseptik dan Booklet

Kegiatan terakhir adalah peserta diberikan kuisioner post test untuk menilai kemampuan sesuadah kegiatan penyuluhan. Kegiatan post test dilaksanakan pada pukul 12.00 WIT bertempat di dusun amaori passo terlihat pada gambar 2. Soal post test disesuaikan dengan bahasa masyarakat awam yang terdiri dari 20 soal dengan pilihan jawaban menggunakan skala guttman. Hasil dari post test ini bermanfaat sebagai evaluasi setelah diberikan penyuluhan yang diharapkan dapat meningkatkan pengetahuan tentang swamedikasi pemberian antiseptik dan pencegahan penyakit rabies.

Hasil dari kuesioner pre dan post test dapat dilihat pada tabel 1. Secara statistik hasil dari pelaksanaan pre test dan post test diuji analisis dengan menggunakan analisis paired sample t-test dengan hasil perolehan adalah $p$ $=0.006(r=0,589)$ dapat dilihat pada tabel 2 . Hal ini menunjukkan bahwa terdapat hubungan pengetahuan antara sebelum dan sesudah 
dilakukan kegiatan penyuluhan. Hal ini mengindikasikan bahwa pemberian swamedikasi pemberian antiseptik dan penyuluhan pencegahan penyakit rabiet sangat mempengaruhi tingkat pengetahuan masyarakat. Terjadi peningkatan pengetahuan setelah dilakukan kegiatan penyuluhan.

Tabel 1. Nilai Hasil Pengetahuan Pre Test dan Post Test

\begin{tabular}{ccc}
\hline NO & PRE TEST & POST TEST \\
\hline 1 & 15 & 17 \\
2 & 2 & 17 \\
3 & 12 & 17 \\
4 & 12 & 17 \\
5 & 12 & 18 \\
6 & 14 & 20 \\
7 & 13 & 17 \\
8 & 18 & 19 \\
9 & 15 & 20 \\
10 & 11 & 17 \\
11 & 9 & 17 \\
12 & 11 & 19 \\
13 & 18 & 19 \\
14 & 19 & 20 \\
15 & 18 & 20 \\
16 & 9 & 17 \\
17 & 15 & 19 \\
18 & 13 & 17 \\
19 & 15 & 17 \\
20 & 14 & 20 \\
\hline
\end{tabular}

Tabel 2. Hasil statistik

\begin{tabular}{|c|c|c|c|c|}
\hline \multicolumn{5}{|c|}{ Paired Samples Correlations } \\
\hline & & $\bar{N}$ & Correlation & Sig. \\
\hline Pair & $\begin{array}{l}\text { PRE TEST \& POST } \\
\text { TEST }\end{array}$ & 20 & .589 & .006 \\
\hline
\end{tabular}

\section{SIMPULAN DAN SARAN}

Berdasarkan hasil pengabdian masyarakat dengan program kemitraan masyarakat yang dilaksanakan di dusun amaori passo, maka dapat disimpulkan bahwa terdapat peningkatan antara sebelum dan sesudah pemberian swamedikasi pemberian antiseptik dan penyuluhan pencegahan penyakit rabies di dusun amaori passo.

Untuk meningkatkan kemandirian masyarakat dalam penanganan penyakit rabies di dusun amaori passo, maka saran yang dapat disampaikan adalah perlu adanya komitmen bersama antara kepala dusun amaori passo dengan 20 orang masyarakat yang telah diberikan pengetahuan swamedikasi pemberian antiseptik dalam pencegahan penyakit rabies dalam meningkatkan kemandirian untuk dapat mensosialisasikan pencegahan penyakit rabies kepada semua masyarakat disekitarnya.

\section{UCAPAN TERIMA KASIH}

Ucapan terima kasih tim sampaikan kepada pihak pihak yang terlibat dalam kegiatan pengabdian masyarakat melalui swamedikasi pemberian antiseptik dan penyuluhan pencegahan penyakit rabies di dusun amaori passo yang dilaksanakan antara lain :

a. Direktur Poltekkes Kemenkes Maluku

b. Ketua Unit PPM Poltekkes Kemenkes Maluku

c. Kepala Puskesmas Passo diwakili staf

d. Kepala Dusun Amaori Passo

e. Ketua RT yang ada di Dusun Amaori Passo

f. Masyarakat yang hadir di dusun amaori passo

\section{DAFTAR RUJUKAN}

Kastania, D. (2013). Analisis Implementasi Kebijakan Penanggulangan Rabies Di Kota Ambon. In Universitas Terbuka. Universitas Terbuka.

Kementerian Kesehatan RI. (2019). InfoDatin: Jangan Ada lagi Kematihan Akibat Rabies. In InfoDATIN.

Kristina, S. A., Prabandanri, Y. S., \& Sudjaswadi, R. (2007). Perilaku pengobatan sendiri yang rasional pada masyarakat. Berita Kedokteran Masyarakat, 23(4), 176-183.

Neurologi. (2016). PENYULUHAN PENGENALAN PENYAKIT RABIES DAN CARA PENCEGAHANNYA DI SD KATUNG KINTAMANI PUSKESMAS KINTAMANI VI BAYUNG BANGLI.

Yusrizal. (2015). Gambaran Penggunaan Obat Dalam Upaya Swamedikasi Pada Pengunjung Apotek Pandan Kecamatan Jati Agung Kabupaten Lampung Selatan Tahun 2014 The Picture of Medication Use In An Effort Swamedikasi On Visitors Pharmacies Pandan Districts Jati Agung Regency Sout. Gambaran Penggunaan Obat Dalam Upaya Swamedikasi Pada Pengunjung Apotek Pandan Kecamatan Jati Agung Kabupaten Lampung Selatan Tahun 2014, 4(1), 446-449. 